\title{
Competencies Required for the Facilitation of Online Learning Courses: An Online Teaching Assistants Competency Based Approach
}

\author{
Motladi Angeline Setlhako \\ Department of Curriculum and Instructional Studies, University of South Africa \\ setlhma@unisa.ac.za
}

\section{Doi:10.5901/mjss.2014.v5n23p1405}

\section{Abstract}

Teaching Assistants also known as e-tutors are unfamiliar with skills needed for teaching at open distance learning institutions. But many open and distance learning systems around the world use the services of part time teaching assistants as a link between students and the university. Globally Teaching Assistants serve as part of the student support network of any open distance education university. Moreover, Teaching Assistants are engaged as a link between the course coordinator, students and the open distance learning institution. They perform various roles such as facilitating learning of subject matter content, stimulating discussion forums, assessing assignments, providing motivation and encouragement, and supporting students on group projects. Each of these roles requires specific competencies to enable them to perform satisfactorily. This qualitative study sought evidence from teaching assistants who have been involved with the UNISA online module over two semesters. The review of literature, observation of interaction between students and teaching assistants and e-mail interviews were used to identify the roles performed by Teaching Assistants at an Open Distance Learning institution and the competencies required for each role in the facilitation of student support and retention. The results showed that teaching assistants were already computer literate before they participated in the online module. They also learnt various skills during the facilitation process but still need to learn more to build their confidence. This study recommends the training of online teaching assistants for use in competence-building to be effective online facilitators.

Keywords: Teaching Assistants, Online facilitators, E-Tutors, E-learning, Competency

\section{Introduction}

Online teaching and learning is a fairly new innovation to South African institutions. As a result of the pressure exerted on South Africa's higher education to transform in order to meet the skills needed in the new South Africa and improve on its policy on performance delivery (De Clercq, 2002; Kistan, 2002), institutions of higher learning are forced to join the new trend of using technology as an alternative mode to teaching and learning. Exciting as it may sound, it is challenging at the same time. All new approaches to human activity require a different mind-set and reorganising one's thinking which Rogers (1995) describes as diffusion of innovation. Online teaching and online learning is described as computermediated, web-based learning environments (Keegan, 1988; Paulsen, 2002; Angeli, Valanides and Bonk, 2003) that require people with different skills to facilitate learning online. Teaching Assistants (TAs), the term used to describe our online tutors, have assumed different roles as the link between students and the university. The roles undertaken require of them to have more competencies than those used in the real classroom to enable them to perform their work satisfactorily. To gain an understanding of the competencies needed to facilitate online learning, the researcher examines the competences of TAs participating in our online module by posing the following question? Do TAs know their roles and competencies needed in the facilitation of online learning courses, student support and retention? This research focuses on the roles that TAs perform and the competences required for facilitation of online learning.

\section{Context of the Study}

The UNISA online module is offered to students who register for a diploma or a degree in education for the first time. The module is compulsory. Students are able to access the module once they are registered with the university and a group is allocated to a TA. At least twenty-two TAs are currently used to facilitate the online module. The module employs an online interactive approach and the researcher as the coordinator of the module used this opportunity to request the twenty-two facilitators to participate in the study. The TAs are recruited within South Africa even though the university, being an Open and Distance Learning (ODL) institution serves a broader community of, national and international 
students. The twenty-two TAs were made aware that the research involves their roles as facilitators of the online course and competencies in an online environment.

\section{Literature Review}

For decades print media dominated the mode of teaching, learning and communication with a vast number of students around the world. With the expanding number of students, the University of South Africa (UNISA) as an ODL institution was compelled to introduce an additional way to provide learning. Technology has brought a new dimension in which communication is instant and quicker than before. As such online teaching and learning, though not a panacea, can also reduce the problems experienced with postal services in delivering learning material to students and submission of assignments. Online delivery of learning material is quicker and instant. However, access to technology also presents another challenge to those students using online for the first time as well as those in rural areas where there is no electricity. Teaching and learning online requires a different kind of workforce, taking up different roles and in need of different skills and competences to facilitate learning.

Depending on how one understands the facilitator of online learning, literature reveals a variety of terminology such as online tutor, online moderator, e-moderator, distance education tutor, e-tutor and teaching assistant (Cornelius \& Higgison, 2000; Conrad, 2004; Denis, Watland, Pirotte, \& Verday, 2004; Bawane and Spector, 2009) to mean the same thing and the duties they perform are exactly the same. However, e-tutoring or online facilitation requires a competent person with specific competencies (Goga, 2006) than those used in the normal classroom. For example, Verval (2007) states that a competent person is "one who effectively and efficiently accomplishes a task in a given context using appropriate knowledge, skills, attitudes and abilities that have adjusted and developed with time and needs. Online facilitation or e-tutoring requires competent individuals with appropriate knowledge and the suitable attitude towards a given task.

However, others argue that there is a difference between a teaching assistant and an e-tutor. Van de Vord, \& Pogue (2012); (Filz \& Gurung, 2013) argue that an online teaching assistant is a student with a record of outstanding performance in that particular course to perform certain tasks as assigned and directed by the instructor or lecturer. However, the duties they perform are similar to those performed by e-tutors. For example, TAs interact with students; evaluate students' work, record students' marks, while some also deal with technical issues as outlined in the study conducted by Van de Vord, \& Pogue (2012). This is similar to an online tutor. Conelius and Higginson (2002); Denis, Watland, Pirotte \& Verday (2004); Goga (2006) point out that an online or e-tutor is a person charged with the responsibility to interact directly with learners to guide and support their learning process when they are separated from the tutor in time and place for some or direct interaction and enables students to learn online. Teaching Assistants and etutors play a crucial role between the institution and students such that e-learning requires of them to possess specific competencies.

Literature also reveals that tutors in an e-learning environment come with a 'baggage' of competencies already formed from the traditional system of learning (Coga, 2006). Although competences from traditional systems of teaching might be helpful, the e- learning system requires more competencies than those from traditional education (Klein, Spector, Grabowski \& de la Teja, 2004; Coga, 2006). For example, Coppola, Hiltz and Rotter (2002); Turnbill (2002); Reid (2003); Bowane and Spector (2009) in studies they conducted found that most online tutors relied heavily on the experience they acquired from face to face settings to facilitate online teaching. However, there is more to online facilitations than face to face. Conceição (2006) emphasises that teaching online demands an understanding of the content, how to present the content, provide a learning environment using technology and take advantage of the unique learning opportunities of online learning environments.

In this case, the flexibility of the situation allows students to access the online environment at the convenience, especially those in asynchronous learning environment. Students can reach the facilitator at their (students) own convenience whereas in face to face, students are at the mercy of the facilitator as they meet at scheduled times at the convenience of the facilitator, for example. Clearly, the platforms for delivery differ from that of face-to-face. The flexible way of accessing the learning environment is more suitable for ODL setting. The online environment has a liberating effect on students and provides a good platform for TAs to encourage students to take control of their own learning. This role develops as one gains experience when working with students at different levels.

\section{Roles and Competencies of Online Teaching Assistants}

Just like e-tutors, online TAs are viewed as the interface between the university and students. The literature reviews show 
that e-tutors or e-TAs have a multitude of roles to play. An ODL environment requires of them to take up multidimensional roles and is also expected to possess a diverse and variety of competencies. For example, they facilitate and guide learning; support and assess student's academic work; solve technical problems; communicate and interact with students and the university extensively; motivate students; build and transmit knowledge, advise, mark assignments and provide feedback on student performance (Ryan, Scott, Freeman \& Patel, 2000; Barker, 2002; Simpson, 2002; Denis; Angeli, Valanides \& Bonk, 2003; Lentell, 2003; Goga, 2006). Nonetheless, Coppola, Hiltz \& Rotter (2002) identifies roles such as the cognitive, affective, disciplinary, managing, evaluative, performing, facilitator, gatekeeper, and boundaryspanner as playing a significant part in online learning. However, what is critical in all of the above mentioned roles is the communication with students as well as the competencies necessary to ensure that learning takes place.

Various English dictionaries define the term competence in many ways. This includes definitions such as capabilities, abilities, skills, aptitudes, and proficiencies; know how, experiences, fitness, and expertise. The above mentioned terms fit in well with Garrison and Anderson's (2003) explanation that a competence implies a set of knowledge, abilities and attitudes which a person can efficiently perform in a way they can attend as expected standards. The variety of definitions given above is thus used to fit the purpose and usage of the argument. Furst-Bowe (1996) also describes competencies as knowledge, skills, and abilities, whereas Schoenfeld-Tacher \& Persichette (2000) views the term differently and as separate skills from competencies. They regard competencies only as knowledge, character traits, abilities and strategies employed by the user. In both situations knowledge of something and abilities to can do something or the work required is imperative for online facilitation of learning.

Beyond that, researchers have been examining a variety of competencies required for online teaching and learning. In their investigation, Reid (2002) recorded more than 500 competencies classified and grouped them into technical knowledge, content expertise, process facilitation, evaluation and course management. Salmon (2000) had previously classified competencies into understanding online processes, technical skills, online communication skills, content expertise and personal characteristics. Shank (2004) used his personal and research experience as well as knowledge of instructional theories and organised his list into five categories, including administrative, design facilitation, evaluation and technical. Dennis, Watland, Pirotte, \& Verday, (2004) generated their list of different types of online competencies as pedagogical, communicational, discipline expertise and technological. The suggestions proposed by UNESCO (2005) did not differ much from the previous suggested categories but included content and pedagogy, collaboration and networking, social and technical issues as well. The differentiated suggestions emanate from the fact that e-tutor or TAs perform countless roles and are therefore expected to possess a wealth of competencies (Denis.et.al. 2004; Klein, et. al., 2004 and Varvel, 2007) to facilitate learning.

The categories listed above do not differ much from each other. They are centred on knowledge and technical skills. However, it depends on the usage as well as the context in which performance of such skills is required. Collins and Berge $(1995 ; 1996)$ looked at various conditions and the various categories presented before, collated and identified the following four as the necessary competencies required:

- Pedagogical competencies had to do with knowledge of the course or module

- Social competencies involves communication and interacting with students and taking care of their online netiquette as well as motivating and encouraging them to participate online

- Managerial competencies includes managing students' work, their interaction, assessing marking, posting announcements and controlling discussions as well

- A technical competency is the ability to use computer and the tools involved in the course, such as internet, emails, opening files, for example.

The researcher adopted the above mentioned categories as they are commonly used in the online environment.

\section{Methodology}

Online qualitative investigation was used to determine the roles and competences required to facilitate online learning. According to Hanna, Weinberg, Dant \& Berger (2005) respondents in online qualitative research are more likely to express their deeper feelings and understanding than during traditional interviews. In this environment, they are less constrained to express their views and more willing to state their opinions more directly than in a traditional interviewing (Pincott and Branthwaite, 2000). In this case, the online qualitative environment provides them (respondent) the liberty to express their opinion without the interference of the interviewer. This means they are in control of their own space and can take their time to respond without fear of being ridiculed. 


\subsection{Participants}

The participants in this study were drawn from the 22 TAs who have been facilitating the module from its inception. They have amassed at least three semesters experience to facilitate the course. The participants willingly volunteered to participate in the study as Vos, Strydom, Fouche and Delport (2012) maintain that no one should participate in a project by force. It would be unethical and risky to force people to participate in any research.

Of the twenty two, only eleven responded within two days and showed willingness to participate in the study. Six of the facilitators have a teaching experience of more than twenty-seven years as high school computer studies teachers. Three are retired technical college lecturers with twelve years high school English language teaching experience including sixteen years communication studies, experience acquired from the technical college. One of the facilitators is completing a Masters' degree in Technology Education as a major and one is currently busy with her doctoral studies in curriculum development while teaching part-time at a private school. All facilitators have background knowledge in education studies:-, an advantage as it will be used to provide background understanding and knowledge of the module. Five of the participants had an advanced training and knowledge in computers, an added advantage.

\subsection{Data Collection}

Although the study relied on review of literature, online observation and online interviews, data was collected at different phases. In the first phase literature was reviewed and secondly the coordinator of the module observed the interaction between the participating TAs and students. According to Hinterberger \& Scheuner (2012), e-observation gives insight into e-learning processes that escape direct observation. They further explain that the researcher collects people's statements about past activities or about intentions and treat these statements as actual behaviour. This kind of data is collected in a non-intrusive way, in real-time (Hinterberger \& Scheuner, 2012). In this study data was collected by gathering statements of students made to their respective TAs and the researcher observed and collated announcements posted to students. The researcher used an observation sheet to categorise the student queries, messages, discussions and announcements posted to students as well as responses from both sides - students and TAs.

The third phase involved the interaction between the researcher and participating TAs. At different points of our interaction and exchange of e-mails, the researcher requested participating TAs to list at least ten competencies they had before engaging in the online course. The lists were returned in two days. Three days later, the researcher requested them again to list the competencies they acquired during the facilitation of the course. The final list was requested at the end of the semester, requesting them to indentify competencies they still need to acquire to ensure they manage their work with confidence and effectively. Data was collected at different times to give them to space and time to think of competences acquired at different periods of times and phases of facilitating the course.

The researcher used e-mail interviews to gather information about the online competencies TAs had before they were involved in online facilitation, during their participation in the module as well as competencies they still need to acquire. E-mail interviewing helps the researcher to reach people who are not easily accessible and/or are geographically far apart and it is cost effective (Meho, 2006) too. The qualitative e-mail interviews were preferred because the strategy was convenient for both the TAs and the coordinator of the module as they were able to exchange multiple e-mails. The exchanges and e-mail interaction took three weeks emulating the asynchronous exchange. The e-mail interview process provided in-depth information which was freely volunteered and was not shared with, viewed or influenced by other participants (Schneider, Kerwin, Frechtling \& Vivari, 2002). The approach was also selected because a qualitative e-mail interview is a better approach for those individuals who are not easily accessible and geographically apart (Clarke 2001; Cassidy, 2010) because of the ODL approach as well as the TAs participating in this course.

All TAs involved in this course are responsible for assessing students work, providing feedback, guiding them on how to go about each assignment and the units. It is their responsibility to motivate students to participate in online discussions and encourage them to submit all assignments throughout the course. All TAs are also encouraged to give student feedback as providing prompt feedback encourages students to improve and strive to do better than the previous assignment. Because the module is a semester course, the study involved participants who have been in the program for at least three semesters.

\subsection{Data analysis}

I divided the lists into three sections, in terms of roles and competences - before, during and still to acquire. 
Table 1: Analysis of roles and competences of TAs at different phases of module facilitation

\begin{tabular}{|l|c|l|c|l|c|}
\hline \multicolumn{5}{|c|}{ Online Roles and Competences } \\
\hline Before & TAs & During & TAs & Still to Learn & TAs \\
\hline Internet skills & 11 & Using of Grade book & 11 & Providing timeous feedback & 9 \\
\hline Download Files & 11 & Using assignment software (jrouter) & 11 & Reaching out to students & 10 \\
\hline E-mailing & 11 & Communicate with students and Faculty & 8 & Easier way to mark Discussions & 5 \\
\hline Microsoft Word & 11 & manage students interaction & 11 & $\begin{array}{l}\text { Ways to encourage students to read } \\
\text { announcements }\end{array}$ & 7 \\
\hline Excel & 11 & Facilitate complex online communication & 10 & Ways to open corrupt files & 8 \\
\hline Discussion Forum & 9 & PDF Creator & 9 & Easy way to post discussions & 4 \\
\hline Facilitate learning & 5 & Leading and controlling online discussions & 7 & $\begin{array}{l}\text { Post announcements to all the groups at } \\
\text { the same time. }\end{array}$ & 6 \\
\hline Discussion Forum & 3 & Familiar with the structure of the module & 10 & & \\
\hline Use Rubrics & 2 & Create groups for online collaboration & 11 & & \\
\hline Social media & 6 & Enforce netiquette & 11 & & \\
\hline Using online marking tools & 5 & $\begin{array}{l}\text { motivate and support the social and } \\
\text { emotional well-being }\end{array}$ & 9 & & \\
\hline Virtual Learning Environment & 1 & Encourage active learning & 11 & & \\
\hline & & Prompt Feedback & 7 & & \\
\hline & & Using online marking tools & 9 & & \\
\hline & & Discussion Forum & 11 & & \\
\hline & & Assessing students' work & 11 & & \\
\hline
\end{tabular}

The most commented on themes emerged from the competencies as identified in the literature. The listed competences relate to the tasks and roles TAs perform in the online course. As such it was not difficult to associate their competences with those categories that are widely used and have been categorised by technology researchers. The TAs educational background and teaching experience played a significant role. For example,

- The pedagogical practices that involve teaching practices and their knowledge helped them to apply their ICT skills in facilitating the online course

- The social skills involve communication with students and promoting a healthy learning experience. Some TAs are still struggling in this category as they are dealing with distance learners for the first time.

- The managerial skill requires facilitators to manage their own group. Each of the groups consists of at least 50 students. Each of the TAs manages at least four groups. However, none of the TAs commented about management of their groups. This aspect is viewed as outside their scope but the responsibility of the course coordinator. The coordinator manages various aspects of the course and as such TAs do not regard other areas of management as their responsibility. The researcher concurs with Collins \& Berge (1995) and Conrad (2004) who also believe that not all four roles (pedagogical, managerial, technical, psycho-social) can be carried out by the same person.

- Technical competencies require facilitators to be able to operate a computer and understand ICT terminology. There are other problematic issues such as the system not operating as required or that the jRouter is often off-line. The facilitator will not be able to deal with issues like this, as it requires an IT specialist to resolve the problem.

\section{Results and Discussions}

Since the focus of the study was based on the roles and online competencies required to perform online learning, TAs were asked to identify the competencies they had before they were involved with the online course. They needed to identify their computer skills, online experience and knowledge. Competencies they acquired during their engagement with the module involves the new knowledge they gathered as they engaged with the module and lastly competencies still to be acquired and learn more in order to function effectively. All of the TAs who participated in the study have an education background and teaching experience at different levels, which played a significant role in the facilitation of the online module. 


\subsection{Online Competencies prior engagement with the module}

Based on the 11 TAs who responded all of them were already competent enough to facilitate the online module. All of the 11 TAs were already computer literate before engaging with the module. They could use internet, e-mails, social media as well as other Microsoft tools such as PowerPoint, and excel. Of all participants, only one was knowledgeable about Virtual Learning Environment (VLE).

Facilitating the module did not present challenges as the majority of TAs possessed the technical skills required to operate a computer. One of the TAs wrote that "I offer computer courses at my school; I therefore have the knowledge and skills as far as this are concerned". One of the advantages was that all had background in education and familiar issues related to being a teacher and marking of students' work. It is no surprise as knowledge of education was an important requirement that was clearly stated when recruiting aspirant TAs. Nonetheless, the majority indicated they relied heavily on their face-to-face classroom teaching experience. Similar studies conducted by Turnbill (2002); Reid (2003); Bowane and Spector (2009) also found that tutors facilitating online learning relied heavily on their face to face experience.

\subsection{Competencies during engagement with the module}

All of the 11 participating TAs gained confidence in both technical and pedagogical abilities to facilitate the online module in the three semesters they had been involved with the module. The list from the 11 participants included learning to use the marking software (jRouter), keeping constant contact with students and faculty, respect diverse learning, ability to manage students' interaction, creating PDF, leading and controlling online discussions. In one of the e-mail exchanges, a TA commented that "I started as an empty vessel in the first semester and I had to learn on the job. Another TA indicated that "I am now confident, this has given me the skills and knowledge and I understand my role as an online facilitator". The coordinator observed some improvement after the first semester, when most of the TAs were no longer and frequently asking questions because of uncertainty. Their interaction with students had improved and encouraging students to participate in discussion forums. They posted announcements prior to the beginning of each unit as directed by the coordinator of the course. This is a clear indication of the confidence gained and gradual improvement in the process.

\subsection{Competencies still to acquire}

The lists received from the 11 participants showed that the number of facilitators needing to acquire certain competences had dropped to four. When asked in the e-mail interview about what they still needed to acquire, the general response from the four and the other seven participants was that it does not necessarily mean they have not yet acquired the skills but they are not confident enough to utilise the skills without guidance or referring to the guide given to them. One TA mentioned that as they deal with many students (fifty in a group), it is difficult to give feedback to each and every individual student, "I end up giving general feedback" and "We are looking for an easier way to can give prompt feedback to each student". Although they still experience some challenges using the jRouter, the onscreen marking tool used to assess students, because of the inconsistent system one TA suggested a practical workshop on finding a quicker way to use jRouter for marking

The majority of participants also indicated they still need to learn better ways to reach out to those students who do not read announcements and fail to respond to messages needing urgent attention. From the various lists the researcher picked up certain skills such as giving prompt feedback, learning the process of sending student marks to outbox to the student system, enforcing netiquette and encouraging active learning.

\section{Conclusion}

As distance education makes greater strides towards e-learning, and the pressure for greater numbers to be admitted to institutions of higher learning as e-students, the need for more skilled tutors and teaching assistants will increase.

Teaching assistants need to be empowered with new skills, in addition to the skills they already possess from their traditional teaching environment. Knowledge of the content of the course only will not be sufficient, and the additional skills will need to be taken into consideration for them to master and develop their competencies.

This can be achieved through structured workshops for teaching assistants which could involve knowledge not only of course content, but also understanding of processes and procedures so that they can respond to queries from students 
to minimise reference to the lead lecturer.

\section{References}

Angeli, C., Valanides, N., \& Bonk, C.J. (2003). Communication in a web-based conferencing system: The quality of computer-mediated interactions. British Journal of Educational Technology, 34(1), 31-43

Barker, P. (2002). On Being an Online Tutor. Innovations in Education and Teaching International, 39(1), 3-13.

Bawane, J. (1999). A study of the discrepancy between the competencies expected and competencies in practice among the primary school teachers. Unpublished doctoral dissertation, University of Mysore, India.

Berge, Z. (1995). The role of the online instructor/facilitator. Educational Technology, 35(1), 22-30.

Bennett, S. \& Marsh, D. (2002). Are We Expecting Online Tutors To Run Before They Can Walk?. Innovations in Education and Teaching International, 39(1), 14-20.

Berge, Z.L., \& Collins, M.P. (2000). Perceptions of e-moderators about their roles and functions in moderating electronic mailing lists. Distance Education, 21(1), 81-100

Coppola, N.W., Hiltz, S.R., \& Rotter, N.G. (2002). Becoming a virtual professor: Pedagogical roles and asynchronous learning networks. Journal of Management Information Systems, 18 (4), 169-189.

Cornelius and Higgison (2001) describe an online tutor as any person undertaking the role of supporting and enabling students to learn online effectively.

Cornelius, S \& Higgison, C. (2001). The Tutor's Role and Effective Strategies for Online Tutoring. Online Tutoring e-Book. OTiS, The Online Tutoring Skills Project, The Institute for Computer Based Learning, Heriot-Watt University, Edinburgh, UK

Cyrs, T. (1997). Competence in teaching at a distance. New Directions for Teaching and Learning, 71, 15-18.

Denis, B. (2003). Quels rôles et quelle formation pour les tuteurs intervenant dans des dispositifs de formation à distance ?. Distances et savoirs, Vol. 1(1)

Dennis, B., Watland, P., Pirotte, S., \&Verday, N. (2004). Role and competencies of the e-tutor. In Proceedings of the Networked Learning Conference 2004. Distance Education, 9(4), 408-414.

Dube, T. (2009). The Role of the Blackboard Virtual Learning Environment (VLE) in Learning Educational Technology, 35(1), 22-30.

Ekkerink, E. (2008). Boundary Spanning Activity: Does Environment Uncertainty Make a Difference. A Research to the Perception of the Dutch Manager of the Dutch SME on the Spanish Market. Masters' Thesis, Radbound University, Nijmagan

Ferry, B., Kervin, L. K., Cambourne, B., Turbill, J. B., Hedberg, J. \& Jonassen, D. (2005). Incorporating real experience into the development of a classroom-based simulation. Journal of Learning Design, 1 (1), 22-32.

Furst-Bowe, J. (1996). An analysis of the competencies needed by trainers to use computer-based technologies and distance learning systems. Performance Improvement Quarterly, 9(4), 57-78.

Garrison, D.R \& Anderson, T. (2003). E-learning in the 21st century - A Framework for research and practice. RouteledgeFalmer, London

Goga, M., (2010). E-competencies of the Tutor in E-learning - A Comparative Study, Proceedings of International Conference on Software, Services \& Semantic Technologies, Sept. 11-12, Varna, Bulgaria, ISBN 978-954-9526-71-4, p. 63, Retrieved on 14 June 2014, https://research.uni-sofia.bg/handle/10506/641 (5p);

Goodyear, P., Salmon, G., Spector, J. M., Steeples, C., \&Tickner, S. (2001). Competencies for online teaching: a special report. Educational Technology Research and Development, 1, 65-72.

Hinterberger, H. \& Scheuner, B. (2012). E-Observation of E-Learning Removes the Guesswork from Didactic Analyses. In T. Bastiaens \& G. Marks (Eds.), Proceedings of World Conference on E-Learning in Corporate, Government, Healthcare, and Higher Education 2012 (616-624). Chesapeake, VA: AACE.

Keogh, K.M and Lorenzi, F. (2002). An Embedded Approach to Learning to Learn Online: Strategies to Increase Student Retention through Developing Subject-based Competence. International Conference on Computers in Education, (1049-1050). Retrieved 9 May 2014 from Kay.mackeogh@dcu.ie francesca.Iorenzi@dcu.ie

Klein, J.M., Spector, J.M., Grabowski, B., \& de la Teja, I. (2004). Instructor competencies: Kogan. Learning Administration, 10(1). Retrieved May 30, 2014, from http://www.westga.edu/

Lentell, H. (2003). The Importance of the Tutor in Open and Distance Learning. In A. Tait \& R. Mills (Eds.), Rethinking Learner Support In Distance Education (64-76). London: RoutledgeFalmer.

Levin, B.B., Ye, H., \& Robbins, H.H. (2006). Comparative analysis of pre-service teachers'

Meho, L.I (2006). E-Mail Interviewing in Qualitative Research: A Methodological Discussion. Journal of the American Society for Information Science and Technology, 57(10):1284-1295

Reid, D. (2002). A classification schema of online tutor competencies. In Proceedings of the Resource-Based Learning. London: Kogan page Limited. Retrieved April, 15 2014, from http://www.learningpeaks.com/instrcomp.Pdf

Ryan, S., Scott, B., Freeman, H., \& Patel, D. (2000). (2000) The Virtual University: The Internet and Resource-based Learning. London: Kogan Page

Salmon, G. (2000). E-moderating: The key to teaching and learning online. London: Taylor

Salmon, G. (2004). E-moderating: the key to teaching and learning online. 2ndedition. London: Routledge.http://www.atimod.com/emoderating/5stage.shtml/.

Schneider, S.J., Kerwin, J., Frechtling, J., \& Vivari, B.A. (2002). Characteristics of the discussion in online and face to face focus groups. 
Social Science Computer Review, 20(1), 31-42.

Schoenfeld-Tacher, R., \& Persichette, K. (2000, July). Differential skills and competencies required of faculty teaching distance education courses. Retrieved August 9, 2014, from http://www.ecel.uwa.edu.au/ijet/v2n1/schoenfeld-tacher/index.html

Shank, P. (2004). Competencies for online instructors: Why have instructor competencies for online instructors? Retrieved 14 April, 2014, from http://www.learningpeaks.com/instrcomp. Pdf

Simpson, O. (2002) Supporting students in online, Open and Distance Learning. Routledge-Falmer, London.

Simpson, O. (2002). Supporting Students in Open and Distance Learning (2 ed.). London:

Smith, T, Fifty-One competencies for online instruction, The Journal of Educators Standards for face-to-face, online, and blended settings. Greenwich, CT: Information Age.

UNESCO. 2005. Regional Guidelines on Teacher Development for Pedagogy-Technology Integration [Working Draft] (Ed S. Majumdar). UNESCO, Bangkok.

Varvel, V. (2007). Master online teacher competences. Online Journal of Distance Learning Administration, 10(1). Retrieved from http://www.westga.edu/ distance/ojdla/spring101/varvel101.htm

Virgil, E. \&Varvel, Jr., (2007). Master online teacher competencies. www.ion.uillinois.edu,

Volery, T. (2001). Online education: an exploratory study into success factors. Journal of Educational Computing Research, 24(1), 7792.

Young, S. (2006). Student views of effective online teaching in higher education. The American Journal of Distance Education, 20(2), 65-77. 